\title{
An Analysis of the Changing of Bigger Thomas' Behavior and Thought in Native Son
}

\author{
Lingdi Chen \\ Dept. of Foreign Languages, Dezhou University, Dezhou, 253023 China \\ Email: chld1973@126.com
}

\begin{abstract}
The thesis analyzes the leading character Bigger Thomas' changing of behavior and mind in the novel Native Son. He changes from an innocent man who has killed several people out of fear from his inner heart to a new black man with self-consciousness and human nature. Although he has been sentenced eventually, he has finished his changing in behavior and mind. Human nature and self-consciousness begin to survive in his mind. Bigger Thomas strongly blows the white men's society at the cost of his tragedy and life.
\end{abstract}

Index Terms - oppress, revolt, human nature, self-consciousness

\section{INTRODUCTION}

When we talk about the famous writer Richard Wright in black American literature history, we can naturally connect him with his famous novel Native son. Indeed, with his special feature, the novel vividly reflects the social situation at that period for the readers and uses unique and brave methods to offer a kind of idea for American to change their traditional mind. Therefore, the novel plays a very important role in the history of American literature and world literature. In the first place, it boldly shows us a black man whose characteristic is very different from the former works about black men, and it vividly pictures the miserable life of American black men living in a slum and the leading character Bigger Thomas and the changing of his mind. After the novel is published, American society is drastically shocked. It is because the novel strongly blows the white American and forces them to realize their oppression to the black men. Meanwhile, it also awakens American black men by forcing them to realize the heavy cost for obeying and bearing the ruling of the white men for so long.

In my eyes, the importance of the novel is: the new generation of black men does not be content with living in the society with the established standards. They hate the law, moral criteria and taboo, which the white men force them to obey. They are acutely aware of white men's hypercritical and superficial appearance, which are used to conceal their oppressive nature. They prefer to die for their basic right and dignity rather than live in the humility like their fathers. At the same time, the white men also suddenly find that all the bad results are caused by themselves and they are never domineers who give the black men fairness and equality. In contrast, the black men nowadays spare no effort to seek freedom and equality, even at the cost of life. The leading character Bigger Thomas in the novel is alien to the features that bear and obey the ruling of the white men and are slaved like Uncle Tom.

From the following several spots, we can easily find how Bigger changes from a man pursuing his own dream and impulse of desire to a man reconsidering the intension of his behavior and mental movement and eventually gets rebirth of mind. His inner heart gets free because of awakening self-consciousness.

\section{The Process OF CHANGING}

\section{A. Bigger Kills the Mouse Cruelly.}

At the beginning of the novel, the readers can be easily attracted by the scene of Bigger's living condition. His living condition is so miserable that the four families live in a very small room. When Bigger's mother and sister take off their clothes, Bigger and his younger brother have to turn away. In such condition, living space and privacy have been totally deprived of. So the human nature has been distorted drastically. Therefore, when the mouse has been found in their room and the frightened mom orders him to kill the mouse, we can feel how cruelly Bigger become.

However, the more terrible is that the position of the mouse has been taken use of by the author to allude to that of Bigger's. And the fate of the mouse insinuates the fate of Bigger.

And we must mention four facts which mutilate him when we analyze the forming of Bigger's behavior. They are race, starvation, broken family and little formal education background. His father dies in a racial riot, and then Bigger, his brother and his sister have been brought up by their mom. They live a very poor life. Because they are black men and their life are also so poor, they have little chance to get education. The four aspects inevitably become the grievous memory in his heart and deeply influenced his thought and behavior. Since Bigger was born, he has been deprived by the society ruled by the whites of the right to choose and he has been ordered to live in the established situation. So when Bigger kills the mouse, "fear" the strong force occupies all his sense, and dominates all his behavior. While the revolt of the mouse stimulates his natural vim pulse, he adopts the very cruel method just as the way to cover his fear in 
his inner heart. "he kicked the splintered box out of the way and the flat black body of the rat lay exposed. Bigger took a shoe and pounded the rat head, crushing it, cursing hysterically: 'You sonofabitch.'In fact, at that time, Bigger has lost human nature, his performance has no difference from the mouse that is confined in the room and has no place to escape. If we recall the scene of Bigger killing the mouse, and compare Bigger with the mouse, we can clearly find that when Bigger is forced to adopt the ruthless method for protecting his families, his face stretches tight, Similarly, for its own safety, the mouse crazily revolts Bigger's assault by the means of counterattacking. Before the mouse dies, it oddly cries. Similarly, when Bigger assaults the mouse and causes the mouse death by his last attack, he also hysterically cries. It hints that the mouse has somewhat potential connection with Bigger. In this phase, Bigger's behavior is senseless, but there is a kind of strange force governing him to have some perverse movement. In fact, the gush of undercurrent of the revolt has emerged in Bigger's heart. And in the near future, the undercurrent will be overwhelming.

\section{B. Bigger Nearly Kills Gears.}

When Bigger attacks Gears at the pool, his oppressed feeling breaks out again. He and Gears plans to rob a shop running by a white man. However, when he realizes his companion feels frightened and holds back like him, his fear gives the way to violence.

When we notice that Bigger threatens Gears with his blade, we immediately recall that Bigger himself is the victim of racism. He thinks that he could rescue himself from the fear by frightening others. He wants to control the situation. However, in fact, his behavior just reflects that he is desperate to his situation and the trend of degeneration. But when we analyze Bigger through this spot, we also cannot omit his humanism. Just like most of the black young men, he also has his own dream and is imaginative. When he waddles on the street with Gears, he can get relax from his pressure. Indeed, Bigger shares his desire with his friend Gears. The desire is "driving plane". When Gears reminds him that the whites would destroy his dream, Bigger doesn't jeer. In contrast, he begins to satire himself and the situation he is living. He turns his anger and grief to satire which could be understood by both. Living in the limited spare ordered by the whites, Bigger thinks over that where he could live, how to live, what does him own and how he treats himself. The spot clearly reflects Bigger's thought, and hints his violent behavior later. At this time, Bigger hates the whites more, and he deeply feels that a somewhat kind of vice is closer to him.

\section{Bigger Kills Mary Unintentionally.}

The phase is very dramatic in the book. In this phase, Bigger stifles Marry. His behavior shocks American society, because he kills a white woman. American legislation rules that if a black man still stays in a white woman's room after 9 p.m, then he violates one of the most important laws and he should be sentenced. Therefore, when he helps drunken Mary go back to her room, he knows his situation is so dangerous. But just at that time, Mary's mother comes into the room, Bigger is caught by a inevitable fear, and his mind is out of control, so he forgets that she is just a blind and weak woman and he can silently escape from the room, at that time, in his eyes, Mary's mother is not a human but a "white ghost". He wants to keep Mary silent, so he naturally covers Mary's head with pillow. And as the result Marry dies.

The result reflects that Bigger hates but fears white men, meanwhile, Bigger becomes "the most vicious black guy" in the whites' eyes. Although the author doesn't narrate the white racists who cruelly oppress the black men, he points out that there are many whites in American society who sympathizes blacks superficially, but in fact they are the domineers to oppress blacks. And the blind mother sympathizes that the white men turn a blind eyes to the problem of racial discrimination. Then it shows deep conflict in American society.

The society Bigger living in too much constrains his thought and emotion too much, and segregates him to a world where he has little chance to keep touch with white men. In this kind of phenomenon, the concept about white men in his mind is blurred because of fear and lacking of belief. In Bigger's eyes, the white men are not just human beings, but a kind of very strong natural power. So it is not difficult to explain why when Bigger sits between Mary and Jane, he feels that he sits between two white walls. And when Mary's mom comes into the room, what he saw is not a weak and blind woman, but a "white ghost". What's more, the society Bigger living in also segregates Black men from each other and the society ruins their determination by economical and social stress and therefore the relations in family weakens. In such society, people confine themselves in their own space and become blind. They become dull and mechanical machine from a flexible and imaginative human beings. All the features, from well-educated Max to silly Bessie are the victims of the society. Therefore, tragedy happens. Mary is killed by Bigger. But she treats Bigger as friends and wants to enlighten and help him. The tragedy makes us have to rethink the unreasonable society.

\section{Bigger Murders Bessie.}

Literally speaking, the murdering is the continuous action of killing mouse and Mary earlier. He hits other's head again. He attacks her by brick and makes her faint. Then he ruthlessly throws her into a well until she is frozen to death. However, the murdering at this time is very different from the last two times in nature. When Bigger tells Bessie what he did and tries to lure Bessie to conspire with him to slander others. She is frightened and afraid of being involved. Her hysteria leads Bigger to realize that she would never escape with him. Could he leave her behind to betray him? Never. Then he begins to premeditate his totally plan to murder. In this spot, his action cannot be explained by enforcing from outside world. It is clear that the whole process is finished deliberately and intentionally.

At the same time, we can also see that the society he living in and the culture influencing him make him largely 
deviate from the normal emotion, as the result, he cannot communicate with others by love, but by hatred, to satisfy his exasperation. Bessie is his mistress, but Bigger doesn't love her but disgust her. Because she is like Bigger, is black. Once Bigger sees her, he connects all other black women in his mind, including his mother and sister. They are weak, silly, poor and humiliated. What they can do is scolding him and urging him to adopt white men's favor to feed them. Therefore, when Bessie becomes his threat, Bigger ruthlessly kills her.

The murdering this time marks that he is reviving in self-consciousness, though the way is very cruelly lopsided. Because the murdering is out of his wish to get balance in mind. At this time, Bigger is never a slave but a free man to pursue his right. It is clearly distinctive with killing Mary unintentionally last time. After murdering Bessie, Bigger begins to quest himself about his action, motive and mental movement. He starts finding his place in the society. Then, self-consciousness emerges in his mind.

\section{E. Bigger Escapes from Home.}

After killing Mary and Bessie, Bigger escapes to Chicago in heavy snow. He is so tired mentally and physically. He feels that he is closely surrounded by whites, and imagines that all the whites are talking about him and hating him because he brings disaster to them. Finally he stops at the roof of a room. "Here marks the transition between Bigger's 'flight' and 'fate'. In this spot, Bigger sees a black family living in one room. Three children crowd on a small bed. Bigger thinks "there are five men living in one room, but on the spacious roof there is only myself." At this time, Bigger examines black men living in a poor and suffering life by his special angle. Although he is also one part of them, he is reconsidering his past life as the outsider. At this time, he gradually realizes how ill-treated they black men get in American society. Although he cannot shake off or transform the present situation, he at the first time in his life really understands the surrounding situation.

Then he is no longer the escaped criminal with fear but the fresh man who can freely thinks and acts. Though policemen encircle him physically, he emancipates mentally from fear that oppresses him for many years.

At that time, because Bigger's thought has shacked off from white men's shackles, he is not the beast surrounded by white men, but new black men when he is arrested.

\section{F. Bigger is in the Prison.}

After being arrested, Bigger lives in the mixed mood of hatred, vice, repentance and fear. At this point, Jane, Mr. and Mrs. Dalton, mother, Bigger's brothers and sister, all of whom crowd into Bigger's jail cell. Mother is sobbing and Bigger feels guilty and is unable to look at her. Buddy, Bigger's brother is as rash and youthful as Bigger and he assures Bigger that he would defend his innocence and get a gun and kill their enemies himself. Buddy's comment is not accepted well and after Bigger learns that his sister Vera, who is ashamed to go to school because her classmates mock her, he feels a mixture of hate and shame. He is ashamed of what he has done to his family. In the prison, he reconsiders his life in the past and reviews all the miserable life he has experienced. He talks to himself in his inner heart. He revives in his mind. He realizes how racism casts his mind and makes him from a ignorant beast to a conscious thinker.

Mental maturation originates from the trial in which Max defends for him and asks him questions. When Max defends for him, Bigger is shocked in his heart. This is not because of the content of the defense, for Bigger doesn't understand what he said, or care if Max can really rescue his life. He is shocked just because of the defense itself - $\mathrm{a}$ white man is defending for a black man. In Bigger's eyes, Max used to be a man from outside space, for there is natural separateness between them. However, being guided by Max, Bigger begins to like talking with him. He tries to explain his "idea" to Max; he needs to "make him know" what he has been trying to express for his whole life. He recounts an earlier conversation when Max asked Bigger the political questions regarding his hate and fear of whites, his economic situation, etc. Bigger focuses on the question of "What would you have liked to do, if you were allowed to?" And he explains to Max that nobody has ever asked him what he has wanted to do, and so he has never spent serious time contemplating a future. Bigger begins to feel like a human and Max's questions helps Bigger realize how badly he has wanted to live. From the talk, Bigger realizes that his fear comes from his inner heart and the emancipation of black men can only depend on black men themselves. At this time, Bigger has no fear and calmly welcomes his rest life.

At the last few days of his life, Bigger revives his human nature, which is very meaningful in his life. He realizes that he has something to do with others. When Jane visits him in prison, Jane says that she has a little blind in the past because she never realizes the great distance between their hearts. At that time, Bigger understands that Jane used to express her belief on him but he himself kills her good friend Mary. Bigger very regrets for what he had done. He deeply feels humiliation for his crime.

Meanwhile, Bigger realizes he has responsibility for his families. But it is too late. Before being sentenced, he pleads Max to tell mother that she needn't to be worry about him because he is well. He realizes all his mother, Jane, Bessie and Mary are the victims of the society and what he had done is not the brave behavior but is out of fear and craze.

After experiencing the miserable life and deliberate thought, Bigger is beyond himself and adopts his situation by his determination. Meanwhile, he enriches his self-consciousness and spiritual world. He can face in a brave and peaceful mood with the fear that tortures him for so long time. Although the change on him cannot revive himself physically for he is to be sentenced, he finds human nature that is deeply hided in his inner heart.

\section{CONCLUSION}


The leading feature of the novel Bigger Thomas is the offspring of the racial discrimination in the society. He has his own dream, like others. He also read newspaper, magazine, watches movies and so on. In fact, Bigger understands his own dream very well. That is, being merged into the society being one part of the world and getting an equal chance though he is a black man. However, he also understands that the dream can never be fulfilled. Indeed, in the novel, the author proves that Bigger's behavior and his attitude to people and society have been decided by his situation in American society. In the established tradition, Bigger should not have his dream and seek it. But ironically, the racial discrimination and inequality enforces him the desire and the seeking to human nature. The changing of Bigger's behavior and mind reflects the reality in the first half of 20 century when black men find their own way to revolt and seek freedom. It is always a warning to the whites society.

\section{ACKNOWLEDGEMENT}

This can be completed in strong support of the dean's guide. Mr. Chen who has a high degree of professionalism, dedication and assiduous work style and bold innovation and entrepreneurial spirit with stringent realistic attitude in his scholarly work, which have an important impact on me,. His vast knowledge, broaden their horizons and gave me quick thinking and deep enlightenment. Meanwhile, in the process I also learned more about black American literature, and the experience has been greatly increased.

\section{REFERENCES}

[1] Barbara Ferman. (1996). Challenging the Growth Machine: Neighborhood Politics in Chicago and Pittsburgh. The university Press of Kansas, Topek.

[2] Carl S. Smith. (1984). Chicago and the American Literary Imagination. University of Chicago Press, Chicago.

[3] Cunliff Marcus. (1987). The Literature of the United States. Penguin Books, Baltimore.

[4] Daniel Oscar Loy. (1893). Poems of the White City. W.B. Conkey Company, Chicago.

[5] William Cronon. (1991). Nature's Metropolis: Chicago and the Great West. W. W. Norton \& Company, New York

Lingdi Chen was born in Dezhou, China in 1973. She received her M.A. degree in linguistics from Shandong University, China in 2003.

She is currently an associate professor in the Foreign Languages Department, Dezhou University, Dezhou China. Her research interests include American literature and interpreting. 